\title{
$\longrightarrow$ MERCADO PENTECOSTAL DE PREGAÇÕES E TESTEMUNHOS: FORMAS DE GESTÃO DO SOFRIMENTO
}

\author{
Mariana Côrtes \\ Universidade Federal de Uberlândia - Uberlândia \\ Minas Gerais - Brasil
}

\section{Introdução}

Um novo campo de possibilidade se abre para sujeitos em condições de vulnerabilidade social, a grande maioria deles habitantes das periferias das grandes cidades brasileiras. Trata-se da possibilidade de se inserir em um mercado emergente: o mercado pentecostal de pregações e testemunhos. Convertidos às igrejas evangélicas, principalmente em suas variantes pentecostais e neopentecostais, esses sujeitos, marcados em suas trajetórias biográficas pela precariedade social, veem como perspectiva o engajamento na carreira de "pregadores-itinerantes", cuja principal prerrogativa é "dar o testemunho" em igrejas e eventos, narrando episódios dramáticos de sua trajetória biográfica, como experiências com a criminalidade violenta, mendicância, prostituição, homossexualidade, doenças, deficiências. A despeito de sua adesão ao pentecostalismo implicar em uma ruptura com a identidade anterior e na aquisição de uma nova identidade religiosa, há, nas narrativas de conversão desses "pregadores", o apelo constante para a "estranheza" de suas identidades pregressas, como "ex-mendigos", "ex-bandidos", "ex-assaltantes", "ex-traficantes", "ex-deficientes físicos", "ex-paraplégicos”, “ex-mudos”, "ex-bruxos”, "ex-macumbeiros”, "ex-homossexuais”, "ex-travestis", "ex-prostitutas", e uma infinidade de outros "ex-". O passado mun- 
dano, que nas conversões clássicas era redimido na aquisição de um novo estatuto purificado, passa a ser permanentemente agenciado como "mercadoria simbólica" a ser vendida em um novo mercado religioso, tanto na forma de apresentações ao vivo como na forma de venda de CDs e DVDs de testemunhos oferecidos aos fiéis depois das pregações ou exibidos nas prateleiras das lojas evangélicas. Quanto mais estranha, grotesca e absurda a história de vida, mais possibilidades de sedução e venda se adquirem.

Nesse contexto, surge um mercado religioso que não apenas oferece respostas milagrosas para as aflições dos novos desesperados, como também passa a oferecer possibilidades reais de ingressos em carreiras de pregadores. Nessas, a precariedade social, que representaria uma moeda de troca negativa na busca por um emprego em um mercado formal de trabalho, torna-se uma moeda de troca positiva. $O$ presente artigo procura então compreender a genealogia desse mercado pentecostal de pregações e testemunhos, e como ele representa uma forma inédita de capitalismo religioso propriamente brasileiro, no qual o "anômalo" das biografias dos moradores das periferias passa a ser agenciado como valor em um processo de acumulação ao mesmo tempo sacral e econômico. No próximo tópico, discutiremos a formação desse mercado de pregações e testemunhos. Para isso, apresentaremos uma descrição da Rua Conde de Sarzedas, em São Paulo, onde se encontra as gravadoras, distribuidoras, estúdios e lojas que movimentam o mercado evangélico de bens simbólicos.

\section{A Rua Conde de Sarzedas}

Localizada na região central de São Paulo, nas proximidades da Praça da Sé e da Praça João Mendes, a Rua Conde de Sarzedas ${ }^{1}$ é considerada o maior centro de comércio evangélico do país e, para alguns, até mesmo da América Latina. Ao longo da rua, veem-se lojas, estandes, galerias, shoppings, livrarias, salas comerciais onde funcionam estúdios, gravadoras e distribuidoras de CDs e DVDs, e editoras, atacadistas e varejistas. São vendidos artigos os mais diversos: ternos, camisas, gravatas, camisetas, blusas, bonés, adesivos com estampas camufladas e emblemas militares como "Exército de Jesus" ou "Eu sou um soldado de Cristo"; túnicas para figurinos de encenação de passagens bíblicas; envelopes para a coleta de dízimos, folhetos de propaganda da prédica evangélica, calendários, cartazes, agendas; louças com inscrições de "mensagens", bandejas e copinhos para água abençoada, púlpitos para pregação, cortinas para decorar igrejas; bíblias de todos os modelos e para todo tipo de clientela.

No mercado evangélico da Rua Conde de Sarzedas é possível também encontrar livros com inúmeros temas, que podem ir desde os que contam a história do pentecostalismo, passando pelos de aconselhamento profissional de pastores até chegar aos que reproduzem a indústria editorial dos livros de autoajuda, clonando assuntos, capas e títulos sob uma temática evangélica. Além dos livros, o comércio de CDs e DVDs é variado: DVDs piratas de filmes hollywoodianos selecionados a partir dos 
enredos de superação; DVDs de filmes de produções locais, que copiam, sob uma roupagem evangélica, enredos de filmes hollywoodianos, com os cartazes fazendo alusão a cenas de blockbusters, mas utilizando-se de atores locais, cujos nomes são pastiches de nomes de celebridades da indústria cinematográfica norte-americana; DVDs de documentários sobre a expansão pentecostal pelo mundo, expondo o triunfo da fé evangélica nos lugares mais recônditos do planeta, das favelas da Nigéria à ilha de Fiji. Ainda no comércio de CDs e DVDs, há os cantores da música gospel, nacionais e internacionais, abrangendo uma infinidade de gêneros musicais. Existem também aqueles gravados por convertidos, missionários, evangelistas e pregadores, que podem vender "mensagens" de evangelização em estúdio ou pregações ao vivo, como podem - o que particularmente nos interessa aqui - vender seus "testemunhos", narrativas em que os adeptos contam sua história de vida pregressa e a posterior "aceitação de Jesus Cristo", marcando um antes e um depois, cuja diferença "testemunha" o poder de Jesus Cristo na operação de milagres e na capacidade de transformar pessoas ou situações consideradas "irrecuperáveis".

Nas lojas dessa rua, a história de vida é anunciada como uma das últimas novidades do mercado. Em meio a livros de autoajuda, bíblias, discos de "louvor a Deus", transeuntes podem, por exemplo, comprar a história do Guina, "ex-Racionais Mc's”, em que se pode ver "um testemunho verídico de um homem que viveu no submundo do crime e das drogas, mas através do evangelho de Cristo conheceu a verdade e hoje convicto de sua escolha conta a sua história de vida". Ou a de Ivandro Amorim:

a história nua e crua da vida de um jovem sem Deus, vivendo como animal, dormindo em cemitérios e comendo restos de comida, nas latas de lixo. Da morte para a vida, uma emocionante história de vida. Irmão Amorim foi condenado a 24 anos de prisão em uma cidade da Patagônia na Argentina. Neste DVD você irá ver cenas marcantes que você jamais esquecerá.

Andando pela rua, ouve-se, no burburinho do comércio, em pequenos grupos de pessoas engajados em acaloradas conversas, comentários sobre os últimos "testemunhos" lançados: "Você já ouviu o do Guina?", "Ainda não"; "Você tem que ouvir. É tremendo!”. E quando eu, estranha em todos os sentidos àquele universo social, temendo ser desvelada na minha marca impura de "não crente", perguntava aos vendedores "Você tem o testemunho do Guina?", ouvia da boca deles uma intrigante satisfação ao me dizerem: "Acabou".

Circulando em meio a este paraíso do consumo evangélico, podemos ver tanto os consumidores comuns, que vão à rua comprar no varejo a infinidade de artigos destinados ao agora chamado "consumidor cristão", quanto os profissionais da religião, evangelistas, missionários, pastores, conferencistas, escritores, cantores, que vão à rua à procura de produtos, serviços, contatos, agendas. Entre esses, há aqueles 
que pretendem investir na carreira de cantores ou pregadores e vêm à rua atrás dos estúdios e gravadoras, que podem tanto gravar os CDs e DVDs como se encarregar de fazer a divulgação, promovendo as mídias e agendando apresentações nas igrejas, vigílias, cruzadas, congressos, encontros, nos inúmeros eventos que movimentam o calendário anual da indústria evangélica de bens materiais e simbólicos. Neste efervescente mercado de produtos e serviços "cristãos", os profissionais da religião ali transitam para ver e dar-se a ver, numa rede de sociabilidade na qual é possível inteirar-se do sucesso de uns e do fracasso de outros, dos bastidores das carreiras e dos eventos, dos últimos fuxicos, incluindo detalhes sórdidos, da vida e atuação dos cantores/pregadores-celebridades. Na rua, busca-se conhecer e ser conhecido, "fazer contatos", "arrumar convites", "ser chamado", participando - ou, na maioria das vezes, lutando por fazer parte - de uma rede de promotores, agentes e intermediários, em alguma medida responsáveis por hierarquizar os destinos, podendo tanto consagrar uns como relegar outros, a esmagadora maioria, ao esquecimento. $\mathrm{Na}$ rua, um jogo social se insinua, e são os sentidos desse jogo que procuramos aqui, ainda que em parte, desvelar.

\section{"A Conde vicia..."}

"A Conde vicia...". Assim sintetizou um dono de gravadora e editor de revista voltada para a divulgação da indústria fonográfica evangélica, explicando-me por que as pessoas que trabalham há anos na "Conde" dificilmente dela saem, mesmo quando a idade avança ou os negócios decaem. Em que consistiria este vício na "Conde", como familiarmente denominam a Rua Conde de Sarzedas os que a frequentam e exercem ali o seu meio de vida? O vício na "Conde" parece condensar em poucas palavras a atmosfera absorvente das relações sociais entre os diversos sujeitos que trabalham e circulam na rua, revelando o caráter impregnante de um jogo social específico, que funciona a partir da formação de mercados particulares: dentre eles, o mercado de hinos, canções e louvores e o mercado de pregações e testemunhos. Iremos nos ater ao segundo.

O comércio evangélico na "Conde" teve início com a abertura da "Gravadora Deus é Amor". A formação da rua como "a rua dos evangélicos" tem conexão com a biografia de um dos mais importantes líderes do movimento pentecostal no Brasil, o missionário David Martins Miranda, fundador da Igreja Pentecostal Deus é Amor. Como me relatou seu sobrinho Roberto Miranda, Davi Miranda começou sua carreira de missionário pregando na Praça da Sé, mais de cinco décadas atrás. Ainda menino, Roberto e sua mãe, Araci Miranda, irmã de Davi Miranda, acompanhavam-no nessas pregações, que ora ocorriam na Praça da Sé, ora em bairros da cidade de São Paulo. À medida que se juntavam transeuntes interessados, Davi Miranda entregava- lhes um papel improvisadamente escrito na hora, contendo o endereço de sua igreja, na época localizada na Vila Maria, bairro afastado do centro de São Paulo. Com o 
sucesso nas pregações e o aumento do número de adeptos, ele decidiu mudar a sede da Deus é Amor para a Rua Conde de Sarzedas, até então apenas uma rua como qualquer outra do centro paulistano. Dona Araci Miranda, observando o talento para o canto de uma das frequentadoras da igreja, teve a ideia de gravar um compacto de hinos e louvores, mas não podia fazê-lo no âmbito da igreja, uma vez que era proibido comercializar dentro do templo. Ela decide então montar uma gravadora e uma loja, alugando uma sala comercial na rua, no número 28 , que depois será transferida para o número 35 , até chegar ao endereço atual, número 237 , onde hoje funciona a "Gravadora Deus é Amor", a mais antiga gravadora e loja da Rua Conde de Sarzedas. De lá para cá, a rua viu seu comércio crescer e diversificar ao longo dos anos, com o aparecimento de várias outras gravadoras, estúdios, lojas, livrarias, estandes e shoppings, cujos empreendedores, motivados pelo nascimento e expansão de um mercado novo e promissor, vieram também tentar sua sorte, abrir seus negócios e ofertar suas mercadorias e serviços. Segundo a avaliação de alguns dos donos de gravadoras e lojas, a rua conta hoje com mais de duzentas lojas e algumas dezenas de gravadoras.

São a essas inúmeras gravadoras, improvisadamente espalhadas em pequenas salas comerciais, que os sujeitos que querem apostar na carreira de cantor ou pregador recorrem. Eles vêm de vários estados do país, do interior do estado de São Paulo, da região metropolitana paulistana ou da própria capital, persuadidos de que têm uma "voz boa", um "jeito para pregação" ou ainda uma história de vida que merece virar "testemunho". Todos, de alguma maneira, supostamente convencidos de que foram "ungidos pelo Espírito Santo" e que "têm uma obra a ser feita em nome do Senhor Jesus Cristo". Em sua grande maioria, as gravadoras, apesar do nome, não gravam as mídias, mas encaminham os aspirantes a cantor ou pregador a algum estúdio, também localizado na rua, que pode tanto produzir a gravação in loco como enviar uma equipe de audiovisual para realizar a gravação ao vivo, nas igrejas ou nos eventos onde cantores e pregadores encenarão suas performances.

Com as mídias prontas, as gravadoras se encarregam de produzir, ou encomendar para empresas terceirizadas, as capas e os layouts dos CDs e DVDs. Em posse das matrizes, as gravadoras podem tanto vender diretamente os CDs e DVDs quanto revendê-los às inúmeras lojas espalhadas pelos shoppings da Rua Conde de Sarzedas. Como os cantores e pregadores, na condição de iniciantes, não ganham qualquer porcentagem por mídia vendida pelas gravadoras, resta-lhes trabalhar totalmente por conta própria, vendendo seus CDs e DVDs na própria rua e também em igrejas e eventos. Dependem, portanto, do trabalho de divulgação, que pode ou não ser realizado pelas gravadoras. No caso das gravadoras se encarregarem da divulgação, os agentes intermediários procuram os promotores de eventos para divulgar seus cantores e pregadores, arrumando convites, fazendo agenda, acertando apresentações. Entre os donos de gravadoras e os aspirantes a pregadores, não há qualquer contrato formal de trabalho ou serviço, ficando as negociações quase sempre sujeitas a acordos informais, de boca a boca. Com a terceirização dos serviços e a informalidade dos 
acertos, sem qualquer exigência de manutenção de um aparato burocrático-jurídico para a regularização formalizada de contratos, as gravadoras funcionam em escritórios enxutos, em apertadas salas comerciais. Na Rua Conde de Sarzedas, essas pequenas gravadoras abrem e fecham numa rotatividade impressionante, disputando encarniçadamente os nichos do mercado e a prosperidade das transações comerciais. "As gravadoras são como lojas de coreanos", me diz um dos donos de estúdio, "todas ali, cada uma tenta sobreviver como pode". A analogia, por surpreendente que pareça, procede. Afinal, as gravadoras evangélicas compartilham com as lojas de coreanos o mesmo modus operandi: funcionam num mercado totalmente informal, extremamente rotativo, operando sobre uma "terra de ninguém" jurídica, onde a desregulamentação dos contratos de trabalho e serviços e a desburocratização dos negócios possibilitam uma espécie de vale-tudo, no qual a palavra de ordem é "salve-se quem puder”, não importando muito se os bens em disputa são os produtos fabricados nas sweatshops asiáticas ou as mercadorias profano-sacrais da Rua Conde de Sarzedas. Paralelamente à competição entre as gravadoras, o imperativo do "salve-se quem puder" aplica-se também para a concorrência entre os pregadores, que lutam entre si por signos de visibilidade e prestígio, disputando com unhas e dentes espaços de atuação neste mercado religioso altamente cambiante e incerto.

Os pregadores, ou aspirantes a pregadores, que procuram a "Conde", estão inscritos numa carreira de pregação específica, distinta das carreiras instituídas no âmbito da religião protestante. Tradicionalmente, existem duas carreiras possíveis: 1) a de missionário, que, movido por uma vocação, se desloca para outras cidades, regiões ou países, no intuito de "fazer a obra", abrindo um novo templo e contribuindo assim para a expansão regional, nacional ou internacional de sua denominação; 2) a de pastor responsável por uma igreja fixa, ocupado com "exercício cotidiano da profissão de cura de almas" (Weber 2000) e com o atendimento das aflições materiais e existenciais de uma comunidade estável de fiéis. No entanto, a expansão do pentecostalismo na sociedade brasileira e o processo de autonomização de um mercado religioso de bens simbólicos, desvinculado do círculo restrito das denominações evangélicas, criaram as condições sociais necessárias para o surgimento de uma terceira modalidade de trabalho religioso: a de pastor-itinerante ou pregador-itinerante, ou ainda missionário voluntário, dependendo da terminologia utilizada. Diferente do missionário que funda um novo templo ou do pastor encarregado de um templo regular, o pregador-itinerante não se fixa em lugar algum, vive do expediente de viajar, pregando onde receber convites para tal. Deslocado de vínculos institucionais com as igrejas, destituído de quaisquer relações contratuais e despregado dos deveres para com um rebanho de fiéis demandante de cuidados permanentes, o pregador-itinerante é um pregador absolutamente desterritorializado, livre dos laços comunitário-congregacionais e das exigências ético-morais a que um pastor de igreja fixa normalmente se vê obrigado.

Sem vínculos empregatícios, o pregador-itinerante é um trabalhador por conta própria, um profissional informal, dependente de convites para pregar e, por isso, 
refém do trabalho de divulgação dos agentes intermediários, como os próprios donos de gravadoras, responsáveis por mantê-lo ou não ativo na disputada rede de contatos em cujo jogo social são lançados os dados que informam os destinos dos sujeitos em disputa no campo religioso. O desenvolvimento de uma carreira itinerante de pregação tem conexão direta com o processo de autonomização de um mercado de pregações. De um lado, a carreira de pregador-itinerante não teria possibilidades sociais de existência se não houvesse um mercado de pregações, ou seja, uma zona aberta, sem marcadores institucionais e identitários rígidos, no qual sujeitos - eles mesmos desterritorializados e nômades - transitam, cada qual ofertando uma moeda simbólica de troca específica e disputando entre si espaços de legitimação no campo religioso. De outro, um mercado de pregações seria igualmente impensável se a carreira de pregação não tivesse se livrado de suas amarras institucionais e constrangimentos morais, desvinculada do pertencimento formal a uma igreja específica e operando fora da rotina regular dos templos.

No mercado de pregações, a concorrência é grande. Sem a segurança institucional das igrejas, o pregador-itinerante é obrigado a investir ao máximo no potencial de sedução de sua performance de pregação, cujo resultado obtido no público de adeptos das igrejas e eventos determinará, em grande medida, sua manutenção ou não na rede de contatos dos agentes intermediários e promotores de evento. Assim, uma clivagem logo se anuncia. Uns farão sucesso, serão presenças obrigatórias nos grandes eventos do calendário anual evangélico, venderão altas tiragens de seus CDs e DVDs, e seus exemplares se esgotarão nas lojas e estandes da Rua Conde de Sarzedas. Outros apostarão todas as suas fichas na carreira de pregador, juntando suas economias e tentando gravar seus CDs e DVDs em uma das tantas gravadoras da "Conde", mas, por serem desconhecidos, dificilmente conseguirão convencê-las a realizar um trabalho de divulgação; contarão, então, com o efeito do boca-a-boca, circularão pela rua, pelas igrejas, pelos eventos, oferecerão seus trabalhos, dirão que têm um testemunho "bom", "forte", "arrebatador", solicitarão convites para pregar. No entanto, muitos desses, a esmagadora maioria, não farão sucesso e nem arrebatarão multidões nos grandes shows evangélicos, permanecendo, o mais das vezes, nas franjas do campo religioso. Ao circular pela Rua Conde de Sarzedas, é possível observar os dois tipos: "o pregador-executivo" e o "pregador-mendicante".

\section{O "pregador-executivo" e o "pregador-mendicante"}

O pregador-executivo é bem vestido, com uma pasta de couro a tiracolo, tem ares de empresário, congrega ao seu redor um séquito de outros pregadores ou aspirantes a pregadores, os quais ouvem atentos ao que tem a dizer, talvez conselhos empresariais e dicas de como se tornar bem-sucedido. Ao pregador-executivo, descrito de forma "típica-ideal" acima, se opõem os que operam nas margens do campo religioso, evangélicos pauperizados, que vendem cartazes com salmos bíblicos nas 
portas das lojas e que, ao menor sinal de interesse, oferecem seus CDs e DVDs e se apresentam prontos para "dar seu testemunho", na expectativa de "receber convites" para "pregar", na esperança de, quem sabe, emplacar na carreira de "missionário", "evangelista", "conferencista". O que ele tem para vender, e que logo se dispõe a vender com uma prontidão impressionante, é apenas a sua própria história, a qual, rapidamente, como quem dá uma amostra do produto que tem à mão, começa a contar a quem empresta os ouvidos. O seu nome pode ser José, João, Paulo, Waldemir, Robson, Geraldo, Edivaldo ou Vilson, cuja história ouvi nas calçadas tumultuadas e concorridas por pedestres e camelôs evangélicos que vendem as versões piratas das mais "quentes" novidades do mercado de canções, conferências e testemunhos. Tomando-me por "crente", Vilson contou sua história, referindo-se o tempo todo a mim como "irmã" ou "pastora", com certeza acreditando que eu pudesse estar "bem-situada" no campo evangélico, sempre uma chance de fazer contatos, de impressionar, de ser convidado para "pregar" na igreja que, supostamente, eu poderia pertencer ou, melhor ainda, poderia ter uma ocupação de prestígio.

Antes de "aceitar Jesus", Vilson foi muitas coisas. Para prová-las, tirou a carteira do bolso e mostrou fotos que confirmavam, em registro visual, a veracidade de suas identidades pregressas. Em uma delas, vestido de cover de James Brown, vê-se uma figura magra, quase esquálida, de talco no rosto e cabelo amarelo espetado, provavelmente simulando um estilo black power. Diz que se apresentava assim, dublando as músicas de James Brown e imitando suas acrobacias dançantes. Em outra foto, está de novo customizado como James Brown. Do seu lado, duas outras figuras aparecem, que ele conta ser seu empresário, vestido de Sérgio Mallandro, e um companheiro, vestido de Hulk. Atrás deles, uma Kombi pintada de cima a baixo com chamadas e propagandas dos shows que a inusitada trupe apresentaria. Depois de ter se aventurado como showman e provavelmente por não ter dado muito certo, tentou a vida como segurança de carro-forte. Na nova fase, mais uma foto para documentar: vestido de segurança, com arma na mão e um tom ameaçador no rosto. Narrando os episódios de sua trajetória biográfica, disse que esteve o tempo todo "enganado". Quando conseguia ganhar algum dinheiro, gastava tudo em bebidas alcoólicas. Cansado da "vida mundana" que levava- "eu estava no mundo" -, decidiu procurar uma igreja e converteu-se num culto da Igreja Universal do Reino de Deus. Não ficou por lá muito tempo, por desconfiança do pastor que demandava "ofertas" exorbitantes, chegando ao ponto de pedir que o novo converso oferecesse a Deus o seu carro. Considerando a proposta ultrajante, saiu da Universal e foi para a igreja Deus é Amor. Também lá não permaneceu, porque, em sua justificativa simples, gostava de tomar banho de mar e assistir televisão, práticas proibidas na referida denominação. Foi então para a Igreja Jesus Cristo é a Resposta, em que se encontra até hoje. Mora em Sapopemba, bairro na zona leste de São Paulo, numa favela. Vive de vender os cartazes de salmos bíblicos, transitando pela "Conde", mas também "dando testemunho" em metrô, ônibus e pontos de ônibus. Se tiver oportunidade de "ministrar", narrando sua história, não 
hesita em aproveitá-la, tanto que, rapidamente, me ofereceu seu telefone de contato e o de outro colega, de "testemunho bom".

Assim, observamos uma segmentação no mercado de pregações. Os pregadores-itinerantes se situam num espectro de legitimidade que vai dos pregadores-mendicantes, pauperizados, marginais, operando nas bordas do mercado, até os pregadores-executivos, verdadeiras celebridades, que viajam pelo Brasil e pelo mundo pregando, cobram cachês altíssimos, têm acesso aos meios de comunicação de massa da indústria simbólica pentecostal, como programas de rádio e televisão, possuem estandes exclusivos na Rua Conde de Sarzedas, onde expõem seus CDs e DVDs e exibem suas trajetórias de pregador-vencedor. Motivados pelo sucesso dos segundos, os primeiros também resolvem apostar na carreira de pregador. Como Vilson, são sujeitos que trazem em suas trajetórias precárias de vida uma sucessão de dramas, como desemprego, desagregação familiar, mendicância, abandono, abusos físico-morais, alcoolismo, dependência química, envolvimento em expedientes violentos, identidades portadoras de estigmas sociais, todos carregados de eventos dolorosos e desesperos recorrentes, experiências que apelam para sua estranheza, seu absurdo, sua imponderabilidade.

Com chances reduzidas de ingressar no mercado formal de trabalho e muitas vezes sem os atributos considerados necessários para engajar nas carreiras tradicionais de pregação, esses sujeitos vislumbram, em meio às possibilidades abertas por um mercado religioso em vias de se consolidar, mas saturados de promessas de sucesso e fórmulas de vitória, a possibilidade de vender o que lhes sobrou para vender, que ainda parece não ter sido desapossado por nenhuma das formas possíveis de expropriação, aquilo que ainda é seu e, acredita-se, somente seu, um bem supostamente inalienável por excelência, mas agora transformado em valor cambiável: sua própria história.

\section{A história de vida como mercadoria}

Andando pela rua, é comum, como no encontro com Vilson, ser abordado por algum pregador-mendicante, pronto para oferecer seus CDs e DVDs de testemunho. Em uma das idas ao trabalho de campo, quando eu descia a "Conde", um homem me abordou: "Irmã, você conhece os meus DVDs?". E logo se prontificou a mostrá-los. Na capa do primeiro, vemos sua foto com as mãos em posição de oração e, anunciando o conteúdo do que o consumidor irá encontrar no produto, os seguintes escritos: "Não tem pudim nem arroz doce: Marreta neles! O tráfico e as matanças continuam, quem vai ganhar mais um bandido para Jesus?". Na contracapa, um foto constando a data de 1982, em que ele aparece moço, trajando apenas shorts, ao lado de um homem, vestido da mesma maneira. Embaixo da foto, lemos o seguinte: "16 anos de idade. Eu como traficante junto com o meu parceiro". Ao lado da foto, temos os escritos: "Ex-trabalho como defunto, carneiro e bode. Morei com Moacir e Eugênio. 
Eram 2 travesti. E tenho prova diante de Deus. Na cidade do Rio de Janeiro". Mais abaixo: "Ex-candomblé, ex-umbanda, ex-ogan, ex-traficante, ex-puxador de samba, ex-negrão do pó". Na capa do segundo DVD, figuram sua foto com as mãos dentro dos bolsos da jaqueta, uma cachoeira e o céu com nuvens brancas ao fundo. Nesse, apareciam os anúncios: "Testemunho, pregação e louvores: Não desista dos seus sonhos, o que você vai assistir neste DVD, meu testemunho que sai da umbanda, da quimbanda e do candomblé, do homossexualismo e da prisão do diabo hoje sou livre para louvar e bem dizer ao Senhor". Na contracapa, em vez de registros em imagem da violência da sua identidade pregressa, havia uma foto de uma paisagem rural idílica e os escritos: "Crente Mentiroso, Crente Capa, Você que Compra e Não Paga. Assista Este DVD". Mais abaixo: "Ex Maconha - Ex Cocaína - O homem que esticava os cabelos com pente de ferro quente - São mais de 500 hinos que Deus me deu, após abandonar as escolas de samba do Rio".

Enquanto me mostrava os DVDs, contava-me pequenos estratos de sua história, oferecendo algumas amostras do que o cliente veria se adquirisse o produto. Narrava que havia sido traficante no Rio de Janeiro, que frequentara "o candomblé, umbanda e toda sorte de macumbaria", que tinha sido homossexual e morado com dois homens, que vivera "sob o jugo do diabo" por muitos anos, mas que tinha aceitado Jesus e, apesar de algumas "recaídas e desvios", havia dois meses que voltara à igreja e encontrava-se "firme no evangelho" de novo. Precavia-me que o testemunho era "muito forte" e que talvez eu me "chocasse" com algumas partes, mas que era "tremendo" e que iria "edificar" a minha vida. Por fim, acrescentou: "se você levar e sentir no seu coração que eu sou de Deus, você pode me convidar para eu dar o testemunho na sua igreja".

Nesse momento, um senhor, vestindo terno e gravata, com os olhos encharcados de lágrimas e a voz balbuciante, interrompeu a conversa e perguntou ao homem com os DVDs: "Você é pastor?". Ele respondeu: "Não". Ainda que um pouco decepcionado com a resposta, o senhor começou a narrar o motivo pelo qual se encontrava naquele estado: "Eu fui expulso, não querem me deixar mais ir, eu fui expulso". O homem perguntou: "Expulso da onde?". "Eu fui expulso da igreja", dizia ele em penúria extrema. "Que igreja?"; "Da Assembleia de Deus, não querem me deixar mais entrar"; "Mas por que fizeram isso?"; "Por causa de adultério", falava com a boca trêmula, enquanto enxugava os olhos. "Eu era presbítero, eu era presbítero, olha minha carteirinha", afirmava enquanto retirava a carteira do bolso e mostrava o documento que provava sua filiação à Assembleia de Deus, com sua foto estampada e o ano de sua inscrição como adepto da congregação. "Eles me expulsaram, me expulsaram, não querem me deixar mais entrar, hoje eu bebi", confessou num misto de vergonha e raiva. Em prantos, continuava a repetir: "Eles me expulsaram, eles me expulsaram". Olhou-me em súplica e perguntou: "Você é crente?". Sem me dar tempo de responder, sentenciou: "Os crente é mau, os crente é mau". E saiu cambaleante pela "Conde", misturando-se às pessoas que subiam e desciam a calçada em busca das 
novidades do comércio, perdendo-se no burburinho da rua e desse mercado onde se compra e se vende, se perde e se ganha, onde estrondosos sucessos ocorrem no passo de silenciosos fracassos, onde milagrosas conversões e poderosos livramentos podem tomar a cena no mesmo espaço em que trôpegos crentes se deparam com os limites de sua fé.

Essa pequena crônica sugere, em um episódio aparentemente banal, a multiplicidade de sentidos dos quais os encontros e desencontros na Rua Conde de Sarzedas podem ser portadores. Em uma mesma cena, conjugam-se um crente desiludido com sua própria crença, humilhado e expulso da comunidade de irmãos na qual congregava há anos, perdido na roda-viva da rua; e um pregador-mendicante, ex-traficante, ex-homossexual, ex-macumbeiro, transeunte recorrente da Rua Conde de Sarzedas, vivendo do expediente de ofertar a mercadoria que, num mercado altamente dinâmico, pujante e competitivo, lhe restou para vender: sua própria história, sua estranheza, sua diferença. No encontro - e desencontro - dos dois últimos personagens, observa-se uma oposição. O primeiro, por conta de um desvio moral, recebe uma punição rígida e implacável: a expulsão da igreja. Desenraizado da rede comunitária que lhe dava segurança e lhe oferecia uma sólida identidade ${ }^{2}$, perambula sem rumo na "rua dos evangélicos" à procura do apoio fraternal que antes encontrava nos laços congregacionais agora destruídos. Na rua, no entanto, depara-se com o espaço sem fronteiras do mercado, destituído de vínculos, regido por relações não fraternais, sem considerações à pessoa e suas privadas aflições. Sem vislumbrar qualquer saída e descrente com seu próprio pertencimento religioso, declara a sentença lógica que lhe sobrou para sentenciar: "os crente é mau". O segundo, despregado de vinculações comunitário-congregacionais, opera no espaço aberto do mercado, cujas prerrogativas internas e "legalidades intrínsecas" (Weber 1982) já lhe foram duramente apresentadas. Nos interstícios do campo religioso, tenta cavar uma brecha de entrada, um lugar possível de atuação. Descobre que existe algo que ele pode vender. Sua história de vida despedaçada, indigna, impura, desvalorizada e rejeitada no mercado formal de trabalho secular, ganha um inesperado valor de troca no mercado religioso. Aqui, ela pode ser produzida, gravada, comercializada, vendida e comprada. Sua identidade estranha e suas extravagâncias de comportamento são capitalizadas na fabricação do seu produto à venda: seu passado mundano como estranho, diferente, anormal.

Sob o crente desiludido e o pregador-mendicante, vemos dois agenciamentos que se opõem: no primeiro, o desvio de conduta é rigorosamente punido com a expulsão da congregação estável de fiéis; no segundo, ele é fomentado, expandido, exagerado na produção de uma mercadoria específica. No primeiro, ainda estamos no círculo fechado e vigilante da comunidade soteriológica de adeptos de uma denominação específica; no segundo, no universo ilimitado e difuso do mercado religioso. Nele, os pregadores-mendicantes investem no seu único trunfo de pregação: a aberração, a anormalidade, o estranhamento de seus testemunhos de vidas pregressas. 


\section{"Mancos", "bastardos" e "ambíguos"}

Operando nas margens e ocupando posições subalternas no mercado religioso, os pregadores-mendicantes utilizam sua condição precária como estratégia performática, escancarando os conteúdos das lutas no campo e denunciando a desigualdade da distribuição de capital simbólico no mercado de pregações. Em um dos DVDs de testemunhos, observa-se uma produção caseira, provavelmente realizada no fundo do quintal da casa do pregador, que improvisou um púlpito com uma cadeira e uma mesinha, cenário que diz ser sua própria igreja. Não há equipes de filmagem ou som, apenas alguém que precariamente filma, numa câmera não profissional, a fala do pregador-mendicante, que aparece de calça, camisa social e paletó, debaixo de palmeiras tropicais, suando em bicas no calor opressivo do Rio de Janeiro. O pregador narra, de forma desorganizada e interrompida, fragmentos de sua carreira de ex-traficante de drogas, ex-macumbeiro, ex-homossexual. Relata episódios anedóticos, estapafúrdios ou esdrúxulos sobre sua vivência no mundo do crime, sua experiência nas religiões afro-brasileiras ou sua condição de homossexual como resultado de trabalhos de feitiçaria dirigidos contra ele. Em meio à narrativa fragmentada, justifica por que destacará apenas alguns fatos de sua vida:

Então a minha vida foi essa, tá, irmão, eu tô contando assim, não tô contando tudo que é para você me convidar, porque se eu contar tudo, tu vai assistir todo o testemunho, e vai dizer: "Negão, assisti tudo, então eu não preciso te convidar". Então, meu irmão, minha vida foi essa, hoje eu sou casado, vocês vão ver no decorrer do tempo desse DVD minha família [ele não cumpre o prometido], que é para vocês não pensarem que eu tô aqui enganando, que eu tô aqui querendo ganhar dinheiro, não tô, irmão, eu espero que esse DVD não me traga dinheiro, mas que traga a felicidade, a paz e o amor na sua vida (Trecho do testemunho de Evangelista Santydoria).

Fica claro que o pregador não poderia narrar toda sua história de vida em apenas um DVD, porque esgotaria, de uma só vez, a única fonte de capital simbólico que possui: seu testemunho. Possuidor de uma única moeda de troca, o pregador deve preservá-la ao máximo, ofertando apenas algumas amostras, fragmentos de sua vida dramática, como se assim pudesse seduzir o consumidor para adquirir futuramente novas porções, novos episódios, novos relatos. O testemunho revela assim sua fragilidade como mercadoria. Como um palito de fósforo que só se risca uma vez, o testemunho é um artigo simbólico efêmero que perde seu brilho tão logo é consumido. Os pregadores inventam subterfúgios para contornar a precariedade constitutiva do testemunho como mercadoria, quando afirmam que não disseram tudo, que ainda há muito mais. Por isso, gravam sequências dos testemunhos, em que são indefinidamente acrescidos 
novos episódios extravagantes à narrativa original, como se a memória pessoal fosse uma fértil terra de ninguém, onde sempre se pode retornar e buscar novas passagens ou potencializar antigas. Mas todo este esforço venal não contém o fato cabal de que há um limite para o testemunho - ele se esgota. Com a produção incessante da narrativa de vida, infatigavelmente requentada, essa começa a produzir refugos de si mesma, cujo resultado final é um produto, que de tão usado, exprimido, fustigado, apresenta-se, então, esmaecido e frouxo, caindo aos pedaços, como uma bricolagem mal costurada, com linhas soltas, composto de pedaços em frangalhos, custando para se manter em pé e superar a fatalidade de sua aparência espicaçada.

Em outro momento do testemunho, o mesmo pregador define sua posição social no mercado religioso:

Irmão, eu vou louvar a Deus daqui a pouco com mais um hino, tá? Nós tentamo louvar a Deus com o "Olha o varão aí!"... Vocês já viram que é uma bença, mas não deu aqui, tá? Na sua igreja aí, eu vou louvar com o "Olha o varão aí!" e vocês vão ver que bença que é. "Olha o varão aí, igreja!". Desemborca os vaso, que tem muito vaso emborcado, que Deus quer encher, que Deus quer dar, que Deus quer usar, que Deus quer trabalhar, que Deus quer movimentar e ele não dá lugar, ah é? [ri] Eu não sou pregador não, irmão, mas abro a boca também para pregar, hein? Mas só que eu não faço apostilas, estudos, que eu não sou conferencista. Eu sou anunciador do evangelho, quem é conferencista é pobrema. Eu não sou, sou anunciador do evangelho. Então, irmãos, eu não sei pregar, mas abro a minha boca, amém, igreja? Então você receba a hora que eu abri e Deus encher minha boca (Trecho do testemunho de Evangelista Santydoria).

Quando começa a pregar sobre o imperativo de "desemborcar" os "vasos", isto é, desobstruir os canais de comunicação dos fiéis com o Espírito Santo, encena uma das estratégias de sedução dos pregadores que visam o arrebatamento emocional da plateia, imitando suas entonações beligerantes de voz e empregando a técnica de gritar acelerado, forte e sofregamente, levando a garganta à extenuação. Logo depois, ele ri, denunciando o próprio pastiche. Distinguindo-se dos pregadores-conferencistas-celebridades, diz que não é pregador, mas que "também abre a boca para pregar”, como se pregasse por usurpação, apossando-se de uma práxis que não é sua por direito, mas da qual se apodera de forma irregular e bastarda, ao mesmo tempo irreverente e envergonhada, posse dos ilegítimos, dos que não podem nem devem, dos que "abrem a boca", mas não deveriam. Diz que não faz "apostilas" nem "estudos", impostando a voz ao falar "estudos", palavra e prática distantes, não familiares, que não se acomodam nos lábios, propriedade exclusiva dos que fizeram cursos, dos que se formaram em teologia, daqueles que sabem. 
De sua condição estruturalmente ambígua no campo religioso, ele narra sua experiência na Rua Conde de Sarzedas e relata a decepção com suas tentativas frustradas de inserção na rede de contatos do mercado de pregações. À sua narrativa de sofrimentos passados, somam-se o relato das humilhações sofridas na "Conde", a desconfiança dos outros crentes e o descrédito de alguns agentes intermediários da indústria simbólica de testemunhos, que lhe recusaram a oportunidade de pregar em igrejas e eventos. Vive pela rua, oferecendo seus DVDs e, quando aparece oportunidade de pregar em algum lugar, não hesita em pegá-la. Oferece prontamente, e sem vacilação, a mercadoria que tem a tiracolo: sua história "aberrante" e "monstruosa", seu passado "grotesco" e "nulo", do qual não pode abrir mão, sob pena de perder o único trunfo que possui num mercado religioso que premia justamente o que o mercado secular repudia.

Em outro DVD de testemunho, há a seguinte narrativa de transformação de vida, conforme anunciado na capa:

O homem que foi macumbeiro e logo após ter saído do seu lar, morou nas ruas de São Paulo como mendigo na praça da Sé. Sobrevivendo com os restos de comida e água de córregos, por esse motivo chegou a pesar 35 kilos. Teve em seu estômago o bixo do lixo (Tapurú). Após ser resgatado por Cristo Jesus, hoje é casado, sua esposa faleceu, mas através de sua oração Deus a ressuscitou. Você não pode deixar de adquirir este DVD.

No DVD, tem-se a pregação de um moço, em torno dos seus vinte anos, esguio e alto, vestindo um terno cor de laranja berrante e calçando um sapato também laranja. A apresentação foi realizada ao vivo durante uma vigília evangélica, provavelmente em alguma escola pública, lotada, com a presença de vários outros pregadores ao fundo do púlpito, aguardando sua vez de pegar o microfone e tomar a palavra. Em meio ao seu testemunho do "mendigo que virou pregador", ele fala, em uma performance altamente teatralizada - quase circense -, sobre o mercado de pregações, posicionando-se no campo religioso contra aqueles que acusa perseguirem apenas a "fama", o "dinheiro" e a "glória" e contra aqueles que se investem de legitimidade teológica desprezando os que carecem de formação pastoral:

É muito bom pregar para multidão? É. Mas quem quer pregar lá na Praça da Sé de madrugada? Ninguém. Chicote vai estralar lindo agora. É muito bom pregar para duas mil pessoas? É. É muito bom pregar em vinte estados do Brasil e dois países? É. Já preguei. Mas quero ver quem quer estar lá três horas da manhã no frio pregando pra trinta mendigos. Ninguém quer. Porque isso não dá fama, isso ninguém ouve dizer, isso ninguém fala: "Fulano pregou e foi mistério". A bíblia diz: Ide e pregai o 
evangelho. Não é querer fama não. A fama é de Jesus. Tem uns bobinho que pega uma malinha e diz: "Eu sou pregador. Eu sou cantor". Você não é nada! Quem é, é Jesus na sua vida, e pronto e acabou. Quero ver quem vai lá comigo pregar na praça da Sé. Pegar... colocar canivete aqui na tua garganta e dizer: "Tu vai dizer o que diz em João 1: 37. Se tu não disser, eu vou cortar tua garganta". Quero ver quem é missionário, pregar para a multidão ficar... (Trecho do testemunho de Wellington Bispo).

Após os gritos de "aleluia" e "glória" do público, ele começa a imitar um pregador supostamente arrogante, de postura altiva, que olha com desprezo, por cima do nariz, as pessoas à sua volta. De repente, interrompe a encenação e começa a gritar violentamente no microfone:

É pó, é pó!!!!! E tá assim. Quando não tá com o microfone na mão, tá assim. Ele só sente a glória quando o microfone tá na mão dele. Quero ver dar glória, dá glória aí, crente! Dá glória, dá glória, dá glória! Porque a teologia diz... Não, não tá na teologia o que o missionário diz... [imitando o pastor arrogante]. Eu não tô nem aí para a teologia, rapaz! Da onde Deus me tirou não foi um teólogo lá me buscar não, foi um pastor que mal sabia ler bíblia, mas que tinha Deus. Deus. Eu não tô aqui para brincar nem para disputar. Foi Deus que me colocou aqui. Ele falou: "Vai lá e entrega tudo". Eu vou entregar tudo, hoje eu tenho uma mensagem de Deus. "Porque a teologia diz que o pastor, pela homilética..." [imitando de novo o pastor arrogante]. Tem que pregar pregado, não pode sair! "Porque pela teologia...". Eu conheço um pregador de longe, ele prega com o diafragma! Dá licença, rapaz, eu pulo, eu grito, eu salto, porque antigamente eu comia lixo, hoje eu tô comendo na mesa com o rei, é com o rei, hoje eu tô com o rei! Porque quando você não tem nome, ninguém te procura (Trecho do testemunho de Wellington Bispo).

Imbuído de sua trajetória de conquista pessoal, o mendigo que virou pregador escancara, em sua performance, as disputas do mercado de pregações, quando denuncia os que pregam pela motivação única da obtenção de "glória" e ridiculariza os que são seduzidos pela promessa de tornar-se um "grande pregador", aqueles que se investem, dos pés à cabeça, das disposições do corpo próprias dos pregadores-celebridades, compondo a héxis corporal dos pastores de renome, acreditando-se também potenciais candidatos a percorrer uma carreira de sucesso, "pegando uma malinha" e se proclamando "eu sou pregador", "eu sou cantor". De sua posição ambivalente e incerta no campo religioso, o mendigo que virou pregador desnuda o jogo social próprio do mercado de pregações, como se, de sua condição desterritorializada e nômade, sem vínculos institucionais com nenhuma denominação e sem contas a prestar 
para quaisquer lideranças eclesiais, pudesse encenar-se iconoclasta - herege e contestador -, acusando tanto os que perseguem a "glória" como os que se ancoram na legitimidade da teologia. Como um mendigo que virou pregador, cuja transformação de vida foi inteiramente mediada, segundo sua própria narrativa, por intervenções sobrenaturais, ele nega a teologia, pois repudia sua pretensão teórica e afirma sua incompetência mágica, ou seja, sua incapacidade de produção dos efeitos desejáveis: milagres, bênçãos, libertações e conversões. Ao rejeitar o caráter intelectualista e cerebral da prédica teológica, declara o poder corpóreo e visceral da prédica emocional: "Porque a teologia diz que o pastor, pela homilética... Tem que pregar pregado, não pode sair! Porque pela teologia... Eu conheço um pregador de longe, ele prega com o diafragma!".

Em seu texto Gênese e Estrutura do Campo Religioso, Pierre Bourdieu argumenta que é preciso investigar quais são as "características sociologicamente pertinentes" que tornam certas biografias singulares, e não outras, socialmente predispostas a assumirem o lugar do profeta, sendo capazes de expressar, com "uma força e uma coerência particulares" (Bourdieu 1999:74), certas demandas não formuladas que se encontram implícitas, esperando uma tradução, entre membros de classe ou de grupo para os quais se destina a mensagem profética. Bourdieu descreve, então, a caracterização sociológica do profeta:

Em particular, seria preciso analisar os fatores que predispõem as categorias e os grupos estruturalmente ambíguos, mancos ou bastardos (palavras escolhidas por sua virtude evocatória), ocupando lugares de grande tensão estrutural, posições inconsistentes e pontos de Arquimedes (por exemplo, os forjadores em inúmeras sociedades primitivas, a intelligentsia proletaróide nos movimentos milenaristas ou, em nível psicossociológico, os indivíduos com status demasiado oscilante) a cumprirem a função que lhes cabe tanto no estado normal de funcionamento das sociedades (manipulação de forças perigosas e incontroláveis) como nas situações de crise (formulação do informulado) (Bourdieu 1999:74-75).

Segundo a sociologia weberiana da religião, o profeta é o grande agente da mudança. Contestador da estrutura sacerdotal vigente e crítico do discurso religioso corrente, o profeta propõe uma reforma da religião instituída ou a inauguração de uma religião inteiramente nova. Inversamente, no universo evangélico da sociedade brasileira contemporânea, a radicalidade da palavra inaugural do profeta, que dissolve o que existe para proclamar o inédito, diluiu-se num mercado onde todos se investem da profecia e se dizem anunciadores das mensagens de Deus. Contudo, se houve uma espécie de banalização da profecia e o profeta parece ter perdido o seu papel de grande contestador da ordem e mobilizador das massas, existe, no mercado evangélico, um nicho destinado àqueles grupos de onde historicamente provinham 
os profetas: os "grupos estruturalmente ambíguos, mancos ou bastardos". São os "ex-tudo", os sujeitos que ocupam, segundo a caracterização de Bourdieu, "lugares de grande tensão estrutural" e "posições inconsistentes" (1999:75). Quando decidem se aventurar no mercado religioso, os "ex-tudo" se arriscam na carreira de pregador-itinerante, expondo, em suas performances de pregação, suas biografias "mancas" e suas identidades "bastardas", vendendo, como a mais última novidade do mercado, suas narrativas de vida espedaçadas, limítrofes, liminares. Compartilham com os profetas da história das religiões monoteístas a mesma condição: o profeta é o personagem que pode falar tudo, porque na maioria dos casos não tem nada a perder. Geralmente exterior à camada sacerdotal burocraticamente organizada, o profeta, como também os atuais pregadores-mendicantes, provém justamente daqueles grupos que não têm contas para prestar nem nomes para zelar, que são simbolicamente destituídos de qualquer signo de distinção e reconhecimento social, e que não possuem, justamente por isso, qualquer obrigação de fidelidade à reputação de estamentos, classes ou grupos particulares. Ambos, os profetas clássicos e os pregadores-mendicantes, se veem livres das amarras da tradição e da honra, e podem propor, por isso, um discurso instável e arrebatador - um discurso ele mesmo bastardo. Mas se o profeta clássico formula um discurso racionalmente coerente, realizando, "através de sua pessoa e de seu discurso como palavras exemplares, o encontro de um significante e um significado que lhe era pré-existente, mas somente em estado potencial e implícito" (Bourdieu 1999:75), os pregadores-mendicantes não elaboram um discurso sistematicamente coeso e veem-se, no mais das vezes, enredados em falas que são, como sua condição social, "ambíguas" e "mancas". São pregações forjadas a partir da combinação desorganizada de passagens do Velho e do Novo Testamento com os episódios dramáticos de suas trajetórias pessoais, improvisadamente costuradas numa bricolagem em que tudo vale, tudo é permitido. Para compreender os sentidos da posição social ocupada pelos pregadores-mendicantes, é preciso investigar a novidade sócio-histórica do mercado pentecostal de pregações e testemunhos, tema do próximo tópico.

\section{O mercado pentecostal de pregações e testemunhos}

Analisar o mercado pentecostal de pregações e testemunhos impõe a breve discussão de como ele se situa no debate teórico sobre a formação do campo religioso e do mercado religioso. Pierre Bourdieu (1999) procurou investigar as condições sociais que possibilitaram a gênese de um campo religioso relativamente autônomo. Bourdieu procurará em Weber as pistas teóricas - e também historiográficas - para a compreensão do processo de autonomização daquilo que Weber havia chamado de "esfera religiosa". E é o sociólogo alemão, portanto, que nos oferece o ponto de partida. Em seu texto Consideração intermediária, Weber (1982) mostra que a esfera religiosa se autonomiza das demais esferas sociais quando o profeta - o grande agente da mudança, como vimos - entra em choque com o clã natural. Weber lembra a 
conhecida passagem bíblica do Evangelho de Mateus (10, 34), em que Jesus diz que só pode ser seu discípulo quem estiver disposto a "hostilizar os membros da casa, o pai e a mãe", sentenciando na frase "Não vim trazer a paz, mas a espada" o corte produzido pelo anúncio profético, o corte que impõe a separação entre a religião e a família, a palavra e o clã, os "irmãos de fé" e os "irmãos de sangue". Para Weber, nessa passagem, fica clara a força desenraizadora da profecia de salvação, quando essa conclama os seus futuros seguidores a abandonar suas comunidades originais, entrando em tensão com a forma de organização social mais primária que existe: o clã natural. O desenraizamento dos indivíduos de seus pertencimentos culturais é condição para que a religião de conversão possa fazer com que o indivíduo agora desterritoralizado se insira em nova congregação soteriológica de fiéis, incorpore um novo sistema significativo do mundo e um novo conjunto de princípios éticos. No entanto, para que o processo de autonomização da esfera religiosa se efetive, a palavra da salvação não pode contar apenas com o carisma extraordinário - e, por isso, mesmo fugaz - da revelação profética. A anunciação do profeta precisa ser "rotinizada" na mensagem cotidianamente emitida por um corpo sacerdotal organizado de maneira burocrática, encarregado de proferir os preceitos éticos da conduta dos homens e atender as demandas materiais e simbólicas de uma camada de leigos unidos por laços puramente religiosos. As condições sociais para a fundação de um campo religioso relativamente autônomo estão assim criadas.

A formação desse campo não levou automaticamente à constituição de um mercado religioso. Esse só se institui a partir da ruptura com o monopólio religioso e a abertura para alternativas sacrais distintas e plurais. Em seu livro O Dossel sagrado, Peter Berger (1985) afirma que, na história do Ocidente, essa situação só se efetivou após as guerras das religiões na Europa no contexto das reformas puritanas, quando católicos e protestantes passaram a disputar a possessão do sagrado e a arregimentação de novos adeptos. No Brasil, a formação de um mercado religioso começa a se configurar na década de 1960 quando outras religiões, como o pentecostalismo, o espiritismo kardecista e a umbanda ${ }^{3}$, começam a concorrer com o catolicismo - até então considerado a religião oficial do país em sua extensa simbiose com a ideia de nação - na busca por novos adeptos em meio à massa de imigrantes que vinham para as grandes cidades em busca do sonho de mobilidade social, que se traduzia simbolicamente, em algumas circunstâncias, no engajamento em uma nova filiação religiosa. De lá para cá, as estatísticas do Censo ${ }^{4}$ demonstram o declínio do catolicismo e a expansão do pentecostalismo, novo quadro que vem sendo objeto de estudo de inúmeros trabalhos das ciências sociais brasileiras, que buscam dar conta da complexificação das disputas por legitimidade dentro do campo religioso e das lutas por almas aflitas no mercado religioso.

Contudo, pouca atenção foi dada à emergência de um fenômeno novo: a formação no Brasil de um mercado pentecostal de bens materiais e simbólicos a partir da década de 60. Na história da constituição da Rua Conde de Sarzedas, a proibição do 
comércio evangélico dentro da igreja estimulou a constituição de um comércio evangélico fora da igreja, abrindo todo um campo possível para a realização de um jogo social, cujo lugar de atuação sai do âmbito restrito das denominações, de suas regulamentações morais e sacrais e suas exigências de respeito à autoridade das lideranças instituídas, para ganhar o espaço aberto do mercado. Vários ramos promissores de negócios, que funcionam para além da rotina regular dos templos, surgiram na esteira do crescimento das igrejas e fiéis vinculados à fé protestante.

No mercado pentecostal de bens materiais e simbólicos, configura-se um nicho voltado para os chamados "ex-tudo": o comércio de testemunhos, no qual se engajam os que se aventuram nas carreiras de pregadores-itinerantes. Aqui adentramos a zona cinzenta do mercado - estamos fora do universo absorvente, vigilante e controlador das denominações pentecostais clássicas, voltadas para a construção de comunidades autocentradas, regidas por redes densas de reciprocidades entre os fiéis. Sem vínculos institucionais com denominações específicas, o pregador-itinerante é um trabalhador por conta própria, que opera no mercado informal de pregações, prestando seus serviços performáticosquando recebe convites para tal. De um lado, o descolamento das obrigações morais e sacrais, que o vínculo regular de trabalho com uma denominação particular exige, pode ser vantajoso para alguns, que operarão no espaço aberto do mercado e se engajarão em carreiras de sucesso, tornando-se pregadores-celebridades. De outro, a ausência de vínculos eclesiais e profissionais com igrejas instituídas pode desapropriar os aspirantes a pregadores de qualquer rede de apoio e segurança, lançando-os num jogo de azar incerto e perigoso, fomentando a formação das carreiras marginais e instáveis dos pregadores-mendicantes.

Desse modo, o desafio de compreender o mercado de pregações e testemunhos passa pela constatação de que o processo de desregulamentação e de precarização do trabalho, próprio do regime de acumulação flexível do capitalismo contemporâneo (Harvey 1996; Boltanski \& Chiapello 1999), instaura suas consequências também no trabalho religioso, cada vez mais refém das flutuações do mercado pentecostal, espaço que não hesita em hierarquizar os destinos dos seus entusiastas a empreendedores. A gestão flexível do trabalho religioso implica, por sua vez, em uma gestão flexível do sofrimento ${ }^{5}$ presente nas experiências dos "ex-tudo", pois o trabalho dos pregadores-mendicantes só é possível como trabalho porque seu ofício é vender uma narrativa performática do sofrimento de suas experiências. A própria possibilidade do surgimento de um "mercado de sofrimentos", contudo, só se efetivou porque o sofrimento recebeu uma resposta inusitada da indústria pentecostal: deixou de ser algo a ser expurgado através da conversão para se tornar algo a ser permanentemente agenciado em um movimento redundante de repetição infinita, encapsulado na abstração fantasmagórica do mundo das mercadorias. No último tópico, discutiremos então como esse processo é indicador do surgimento de um capitalismo religioso brasileiro, capaz de oferecer soluções inovadoras, próprias de um novo management flexível, para as renitentes fraturas da nossa sociedade. 


\section{Um novo capitalismo religioso e a gestão flexível do sofrimento}

Esta nova e inaudita gestão flexível do sofrimento só se torna compreensível quando observamos que a carreira de pregador-itinerante - na qual o que se vende é o "sofrimento espetacularizado", que deve ser exibido, dramatizado, midiatizado - se insere em um novo regime de governamentalidade ${ }^{6}$, no sentido que Michel Foucault (2008a; 2008b) fornece ao termo. Para Foucault, esse novo regime de governamentalidade - por ele denominado de neoliberal - se institui a partir das mudanças da sociedade capitalista na década de 1970. No Brasil, a instituição desse novo regime de governamentalidade pode ser observada a partir da década de 1990, quando se tem um ponto de inflexão na história do país. A década anterior havia sido marcada por importantes movimentos sociais de luta por amplificação dos direitos e por melhoria das condições urbanas. Contudo, a crença de que as promessas não realizadas da modernidade se fariam valer na sociedade brasileira e de que a maioria da população alcançaria o universo de uma cidadania ampliada não se realizou (Telles 2010). A hipótese superadora se esvaziou na década seguinte. Sob uma das tantas ironias da história, no momento em que o país se redemocratizava, ele encontrava em curso no cenário mundial um processo de instituição das políticas neoliberais, que nos países centrais significava o desmantelamento do Estado do Bem-Estar Social e a adequação a um padrão flexível de acumulação capitalista (Harvey 1996; Boltanski \& Chiapello 1999). A pragmática neoliberal introduz uma espécie de nova fatalidade: o horizonte de igualdade e a busca pela extensão dos direitos sociais saem da agenda política (Foucault 2008a; 2008b). Não se trata mais de construir uma ordem mais justa, igual, democrática, e sim gerir as consequências da nova desordem, resultado da desregulamentação da economia e da abertura da "caixa de pandora" do mercado, cuja máquina milagrosa do capital financeiro - que nos seduz com a fórmula fantasmagórica do dinheiro que procria dinheiro -, deixa no seu rastro milhares de "vidas desperdiçadas" (Bauman 2005), incapazes de acompanhar o frenesi da aceleração permanente e da mobilização total. A desigualdade, a pobreza, a violência, não serão eliminados ou concretamente combatidos, mas geridos. Gerir a desordem ou, nos termos de Chico de Oliveira (2003), "administrar a exceção". Com a instituição do novo "princípio gestionário" (Telles 2010), a exceção - que antes constituía os avatares do atraso a serem superados pela realização plena das promessas da modernidade - torna-se a regra.

O fim da "hipótese superadora" e a difusão do fatalismo neoliberal mudaram a vida dos sujeitos nas periferias das grandes cidades brasileiras. Gabriel Feltran (2008) mostrou como os quadros de referências que haviam mobilizado a vinda de migrantes desde os anos 1960 para São Paulo para ocupar postos de trabalho na indústria e construir a casa própria nos bairros periféricos foram profundamente alterados a partir da década de 1990. A crença na ascensão social da família, a garantia de emprego apoiada em sindicatos atuantes, os movimentos eclesiais de base da Igreja Católica 
que aliaram fé cristã e luta por melhorias urbanas, fortemente presentes no cenário dos anos 1980, saem de cena nos anos 1990, quando a paisagem das periferias passa a ser formatada por uma nova configuração societária. Na nova configuração, o horizonte do emprego fordista cede lugar ao desemprego, ao emprego flexível e aos subempregos, o mundo do crime se afirma como uma opção possível para os jovens, a Teologia da Libertação entra em declínio no mesmo passo que se proliferam por todos os lados igrejas neopentecostais prometendo a libertação dos demônios e a conquista da prosperidade. O boom do crescimento evangélico a partir da década de 1990 no Brasil se insere nesse processo?

Acompanhando a multiplicação das igrejas, deu-se a formação de um exuberante mercado pentecostal de bens e serviços, que inclui o submercado de pregações e testemunhos, nos quais os candidatos a pregadores-itinerantes lutam por se inserir. No entanto, quando o fazem, não rompem com o seu passado anterior na conquista de uma nova identidade sacralizada; pelo contrário, agenciam as desgraças de sua história de vida pregressa como mercadoria simbólica a ser vendida no mercado religioso. Nesse sentido, o sofrimento presente nessas biografias não será expurgado, mas "funcionalizado" (Oliveira 2003) por esse capitalismo propriamente religioso. As respostas ao sofrimento empreendidas pela indústria simbólica pentecostal surpreendem por sua inventividade quando se tem em conta sua capacidade, extremamente eficaz, de adequação às condições sociais ambivalentes de muitos dos sujeitos "mancos", "bastardos", "ambíguos" que compõem o espectro de estranhos sociais da sociedade brasileira contemporânea. Os chamados "ex-tudo" não são previamente rejeitados pelas empresas simbólicas pentecostais por carregarem signos de estigmatização demasiadamente insuportáveis. Ao invés disso, no espaço desterritorializado do mercado religioso, há um lugar - ainda que precário - destinado a eles. Refugo dos processos diruptivos da máquina de aceleração capitalista não sacral, os "ex-tudo" são reincorporados, exatamente por sua qualidade de refugo, por uma máquina de aceleração capitalista alternativa, que se diz sacral. A indústria simbólica pentecostal pode ser interpretada como uma grande agência de absorção de sujeitos que se encontravam nas margens dos processos de acumulação capitalista, de retroalimentação dos "subprodutos" gerados pela pulsão modernizante da sociedade brasileira. Assim, poderíamos dizer que essa grande invenção da indústria pentecostal brasileira, que transforma o refugo das biografias dos habitantes das periferias em mercadoria, se institui como uma das formas mais criativas de "administração da exceção" ou gestão da desordem. Afinal, os signos de infâmia dos "ex-tudo" não são combatidos através de um trabalho de purificação ou construção de uma nova ordem moral, mas agenciados como capital-investimento no mercado religioso. Quando esse os absorve, o faz não como objetos que podem ser "recuperados" e devem ser "moralizados", mas justamente por suas atribuições de resto, por aquilo que suas condições de vida trazem de ambivalência. Os "ex-tudo" não passam por um processo de reforma, conversão e transformação, não são remendados, consertados, ajustados. Se o fossem, 
perderiam a única moeda de troca que possuem para negociar sua legitimidade no comércio religioso: suas identidades liminares.

Desse modo, nos novos conteúdos da conversão religiosa no campo pentecostal/neopentecostal, opera-se um processo inédito: a conversão não implica mais em uma ruptura com o antigo eu e a adoção de um eu eticamente renovado, mas em um curto-circuito consigo mesmo. Em seu trabalho sobre as narrativas de conversão, Clara Mafra mostrou que a ideia tradicional de conversão como "processo de virada dramática na trajetória individual” (2000:58), não poderia se aplicar mais ao contexto de expansão dos movimentos pentecostais contemporâneos, uma vez que esses eram "fortemente marcados por uma maior fragilidade, vulnerabilidade e pelo caráter pouco exclusivo e totalizante das novas adesões" (2000:58). Para Mafra, aderir à nova religião não significa necessariamente abandonar o passado, mas entre o antigo eu e o novo eu pode-se abrir "um campo amplo de interlocução", que permite "um espaço de negociação entre os sistemas simbólicos em relação" (2000:58). O trabalho de Clara Mafra tem o mérito de mostrar como as agências pentecostais de arregimentação de fiéis operam com uma lógica distinta dos modelos clássicos de conversão, pois introduzem um mecanismo de flexibilização ao abordarem de forma diferente as identidades de seus futuros adeptos, "incorporando, cada vez com maior facilidade, as referências e diferenças pessoais como recursos internos" (Mafra 2000:68). Contudo, ainda que eu concorde com as observações de Mafra sobre a mudança profunda nos conteúdos de conversão, o presente trabalho segue outra direção. Se, de um lado, a flexibilização da conversão permitiu uma maior autonomia dos sujeitos no processo de reconstrução de si mesmos, como afirma Mafra, de outro, permitiu a criação de um mercado que transforma a identidade pregressa - quando portadora de algum signo de infâmia social - em mercadoria simbólica a ser trocada no comércio religioso. Aqui, "as diferenças pessoais como recursos internos" (Mafra 2000:69) são agenciadas como artigos à venda. Assim, na dinâmica das conversões, há a introdução de um dado novo que estava ausente no contexto das narrativas de conversões estudadas por Mafra: o surgimento de um mercado de pregações e testemunhos no interior do movimento pentecostal.

Toda a espetacularização da narrativa dos pregadores-itinerantes está no passado mundano, que apela para o grotesco das experiências pregressas, passado do qual os depoentes não podem escapar posto que é permanentemente presentificado nas performances de pregação. Constata-se então que a legitimidade do testemunho comercializado não tem como fonte o corte na trajetória biográfica, separando rigidamente o antes e o depois da conversão, o ser e o dever ser, e glorificando o milagre da transformação radical de vida perpetrado pelo poder de Jesus Cristo. Ao contrário, o testemunho tem como trunfo justamente o espaço intermediário entre o que a pessoa foi e o que pessoa diz ser agora, espaço liminar no qual as duas identidades, a identidade mundana e a identidade de crente, trocam constantemente de lugar, num jogo em que é agenciada, como mercadoria simbólica, a condição bastarda dos "ex-tudo". 
Os pregadores-mendicantes veem-se condenados à repetição compulsiva e inesgotável do inaudito de seus dramas, aprisionando-os numa narrativa em que se veem obrigados a encenarem, nas performances no palco, perpetuamente o que são - suas identidades estranhas, suas condutas anormais, suas disposições aberrantes -, em um círculo vicioso e inescapável, encerrado na tautologia da definição imanente do ser o que se é.

Em seu livro O que resta de Auschwitz, Giorgio Agamben comenta que Auschwitz representa uma "ruptura decisiva" em relação à possibilidade do "eterno retorno" como "superação nietzschiana do ressentimento". Como crítica da moral judaico-cristã, Nietzsche propõe que o passado não deve ser enterrado sob o peso da culpa e da crise de consciência, mas, ao contrário, deveríamos ser capazes de assumi-lo totalmente, desejando que ele sempre volte e seja dotado da potência de se repetir. Como diz Agamben, "o eterno retorno é, antes de tudo, vitória sobre o ressentimento, possibilidade de querer o que foi, de transformar todo 'assim foi' em um 'assim quis que fosse' - amor fati” (2008:104). Para Agamben, Auschwitz marca, contudo, um corte brutal em relação à proposição ética do "eterno retorno". Não apenas porque é demasiado absurdo desejar a repetição da experiência atroz dos campos, amando-a "como um destino", mas também porque, de forma ainda mais grave, desejar o "eterno retorno" de Auschwitz é redundante, uma vez que, como intui a percepção fina de Primo Levi, Auschwitz "nunca deixou de acontecer, já se está repetindo sempre" (Agamben 2008:106). Nas narrativas dos testemunhos dos "ex-tudo", percebe-se uma injunção ao "eterno retorno" das experiências passadas, não como possibilidade ética de superar o ressentimento ou como uma decisão de amar o próprio destino, e sim como uma imposição à eterna repetição do mesmo, acrescido, conforme as exigências de um mercado altamente rotativo e competitivo, de novos eventos, numa roda-viva de episódios fragmentados nos quais o que se comercializa são os horrores da história de vida. Se, depois de Auschwitz, propor o "eterno retorno" ora se tornou um ultraje, ora se tornou uma redundância, no mercado evangélico de bens simbólicos, o "eterno retorno" é o próprio modus operandi do comércio de testemunhos, em que sujeitos sociais como os "ex-tudo" se veem arremessados numa repetição infinita de suas próprias dores, reafirmando em demasia um destino que dificilmente poderíamos dizer que amam.

As narrativas de conversão oferecem a seguinte imagem: uma cobra perseguindo seu próprio rabo, sendo que aqui é o próprio movimento fútil, repetitivo e dispensável de narrar à exaustão sua precariedade social e moral que permite - até sua próxima descartabilidade - a permanência dos "ex-tudo" no competitivo mercado de pregações. Em outros termos, é o precário prestando-se à acumulação de valor da indústria neopentecostal de "reciclagem do lixo humano" (Bauman 2005). Nos horizontes dos sujeitos que vivem nas periferias das grandes cidades brasileiras, marcados por dramas sociais variados, surge uma nova possibilidade de carreira, em que a vida matável e insacrificável de múltiplos homini sacri (Agamben 2002) transforma-se em 
mercadoria simbólica. Observa-se então no Brasil a emergência de um mercado de sofrimentos, uma das mais surpreendentes invenções desta forma de capitalismo religioso à brasileira, em que o anômalo é transmutado em alavanca da acumulação, ao mesmo tempo econômica e sacral.

\section{Referências Bibliográficas}

AGAMBEN, Giorgio. (2002), Homo sacer: O poder soberano e a vida nua I. Belo Horizonte: Editora UFMG. . (2008), O que resta de Auschwitz. São Paulo: Boi Tempo.

ALMEIDA, Ronaldo de. (2009), "Pluralismo religioso e espaço metropolitano". In: R. de Almeida \& C. Mafra (orgs.). Religião e cidades: Rio de Janeiro e São Paulo. São Paulo: Terceiro Nome.

BAUMAN, Zygmunt. (2005), Vidas desperdiçadas. Rio de Janeiro: Jorge Zahar Editor.

BOLTANSKI, Luc \& CHIAPELLO, Éve. (1999), Le nouvel esprit du capitalisme. Paris: Gallimard.

BERGER, Peter. (1985), O dossel sagrado: elementos para uma teoria sociológica da religião. São Paulo: Paulinas.

BOURDIEU, Pierre. (1999), A economia das trocas simbólicas. São Paulo: Perspectiva, 5⿳a ed.

CAMARGO, C. P. F. de. (1973), Católicos, protestantes, espíritas. Petrópolis: Vozes.

CÔRTES, Mariana. (2007), O bandido que virou pregador. São Paulo: Aderaldo \& Rothschild Editores; Anpocs.

DEJOURS, Chistophe. (1999), A banalização da injustiça social. São Paulo: Editora FGV, 7ํㅜ ed.

FELTRAN, Gabriel Santis. (2008), "O legítimo em disputa: As fronteiras do "mundo do crime" nas periferias de São Paulo". Dilemas: Revista de Estudos de Conflito e Controle Social, v. 1: 93-126.

FOUCAULT, Michel. (2008a), Segurança, território, população. São Paulo: Martins Fontes. (2008b), Nascimento da Biopolítica. São Paulo: Martins Fontes.

HARVEY, David. (1996), Condição pós-moderna. São Paulo: Loyola.

MAFRA, Clara. (2000), "Relatos compartilhados: Experiências de conversão ao pentecostalismo entre brasileiros e portugueses". Mana, vol. 6, n. 1: 57-86.

MARIANO, Ricardo. (1999), Neopentecostais: sociologia do novo pentecostalismo no Brasil. São Paulo: Loyola.

OLIVEIRA, Chico de. (2003), “O estado e a exceção ou o estado de exceção?”. Revista Brasileira de Estudos Urbanos e Regionais, vol. 5, n. 1: 9-14.

PIERUCCI, Flávio \& PRANDI, Reginaldo. (1996), A realidade social das religiões no Brasil: Religião, sociedade e política. São Paulo: Hucitec.

RENAULT, Emmanuel. (2008), Souffrances sociales: philosophie, psychologie et politique. Paris: La Decouverte.

TELLES, Vera da Silva. (2010), A cidade nas fronteiras do legal e do ilegal. Belo Horizonte: Editora Fino Trato.

WEBER, Max. (1982), Ensaios de Sociologia. Rio de Janeiro: Guanabara Koogan, 5aㅡ ed. . (2000), Economia e Sociedade. Vol. 1. Brasília: Unb, 4르 ed.

\section{Notas}

1 Fui pela primeira vez à rua em 2002, por ocasião da minha pesquisa de mestrado sobre a conversão de ex-criminosos para o pentecostalismo (Côrtes 2007). 
2 A igreja pentecostal Assembleia de Deus, da qual fazia parte o crente desiludido, mantém a exigência de rigidez moral aos seus membros, vigiando e punindo condutas consideradas irregulares, como o adultério. Como mostra Ronaldo de Almeida, o pertencimento a essa denominação gera "um tipo de sociabilidade 'congregacional' [...], de algumas lideranças tradicionais e/ou carismáticas e de fortes vínculos afetivos e sociais de longa duração" (Almeida 2009).

3 Os estudos de Cândido Procópio Ferreira de Camargo são pioneiros no Brasil na análise da configuração desse novo mercado religioso. Cf. Camargo (1973).

4 Segundo os dados do Censo do IBGE, em 1970 havia 91,7\% de brasileiros católicos; em 2010, eles passaram para 64,6\%. Em contrapartida, em 1970 havia 5,2\% de evangélicos no Brasil; em 2010, eles totalizaram $22,2 \%$ da população brasileira.

5 A questão do sofrimento vem se tornando cada vez mais central nas pesquisas recentes das ciências sociais. O livro Souffrances sociales: Philosophie, psychologie e politique, de Emmanuel Renault (2008), mapeia como a problemática do sofrimento social vem se inserindo no debate das ciências sociais, principalmente sob o impacto das produções recentes de desfiliação social engendrada pelo neoliberalismo. Um autor que contribuiu para colocar o sofrimento na pauta dos estudos acadêmicos foi Christophe Dejours (1999), que estuda o impacto das transformações do mundo do trabalho na subjetividade dos trabalhadores, principalmente sob a instituição de uma nova banalização da injustiça social. Nesse trabalho, pressupõe-se que o sofrimento presente nas narrativas de conversão dos pregadores-itinerantes tem uma gênese social nos processos intensos de desfiliação social promovidos pelo neoliberalismo. Contudo, para fins do artigo, interessa-nos focar na compreensão de como os próprios pregadores-mendicantes transformam esse sofrimento (socialmente produzido, sem dúvida) em mercadoria simbólica a ser vendida no mercado religioso.

6 Foucault formula o conceito de governamentalidade pela primeira vez no curso ministrado no Collège de France em 1978, intitulado Segurança, Território, População. No curso do ano seguinte, intitulado Nascimento da Biopolítica, ele retoma o conceito para investigar o surgimento de uma governamentalidade propriamente neoliberal. Para Foucault, governamentalidade significa uma determinada pragmática que visa responder uma pergunta específica: como conduzir a conduta dos homens.

7 Sobre a expansão pentecostal e neopentecostal na sociedade brasileira, ver Pierucci \& Prandi (1996), Mariano (1999), Almeida (2009).

Recebido em outubro de 2013. Aprovado em junho de 2014.

Mariana Côrtes (mmpcortes@incis.ufu.br)

Professora Adjunta do Instituto de Ciências Sociais da Universidade Federal de Uberlândia. Doutora em Ciências Sociais pela Universidade Estadual de Campinas e Mestre em Sociologia pela Universidade de São Paulo. 


\section{Resumo:}

\section{O mercado pentecostal de pregações e testemunhos: formas de gestão do sofrimento}

$\mathrm{O}$ presente artigo tem como objetivo investigar a emergência de um mercado pentecostal de pregações e testemunhos, no qual sujeitos engajam-se nas carreiras de "pregadores-itinerantes", vivendo do expediente de "dar seu testemunho" em igrejas e eventos. Narrando episódios dramáticos de seu passado mundano, esses sujeitos lutam para se inserir nas margens de um mercado religioso instituinte, transformando suas biografias despedaçadas em mercadorias simbólicas. Nessa indústria pentecostal do sofrimento, sujeitos considerados "subprodutos" da modernização são absorvidos por suas qualidades de "resto", por aquilo que suas identidades estranhas portam de ambivalência. Observa-se assim a constituição de um mercado de sofrimentos, uma das mais surpreendentes invenções desta forma de capitalismo religioso à brasileira, em que o "anômalo" é transmutado em alavanca de acumulação.

Palavras-chave: Mercado pentecostal, pregadores-itinerantes, gestão, sofrimento, capitalismo religioso.

\section{Abstract:}

\section{The Pentecostal Market of preaching and testimonies: forms of suffering management}

The paper investigates the emergence of a Pentecostal market of preaching and testimonies, in which individuals engage themselves in the careers of "itinerant-preachers", "giving their testimony" in churches and events. Through the narratives of dramatic episodes of their past, these individuals struggle to be included at the margins of religious market, converting their shattered biographies into symbolic commodities. In this Pentecostal industry of suffering, subjects considered "subproducts" of modernization are assimilated due to their character of "rest", due to the ambivalence their strange identities provide. Therefore, it is analyzed the construction of a sufferings market, perhaps one of the most surprising inventions of the 'Brazilian way' form of religious capitalism, in which the "abnormal" is transmuted in a lever for accumulation.

Keywords: Pentecostal market, itinerant-preachers, management, suffering, religious capitalism. 